\title{
STRATEGIES TO CONQUER THE SOUVENIR BUSINESS: CASE STUDY OFLAPIS TALAS CAKE BOGOR
}

\author{
Ahmad Ridho*)1, Idqan Fahmi*), and Siti Jahroh*) \\ *) School of Business, IPB University \\ Jl. Pajajaran, Bogor 16151
}

\begin{abstract}
The objectives of this study are 1) to analyze the effect of marketing mix, brand awareness, brand image and region of origin on lapis talas purchasing decision for tourists in Bogor city, 2) to create effective marketing strategies for business development. Using SEM-Partial Least Square method,this research was conducted in the city of Bogor with the sample of 160 respondents. The selected respondents were tourists who came to the city of Bogor and had purchased lapis talas cakes. From the results of the study, it is known that the brand awareness variable, brand image, product, promotion and region of origin have a significant influence while the place variable has no significant influence. Strategy recommendations suggested in this study are 1) Increase brand awareness by increasing the intensity of advertising on social media, building outlets in tourism areas and train stations; 2) Improve product quality by providing packaging machines, making plastic bags, enlarging product sizes and adding fruit mixes; 3 ) Improve regional characteristics by adding taro ingredients and making a brand that is identical with the city of Bogor; 4) Build brand image through tagline; 5) Increase promotion using online media (facebook, instagram and twitter), billboards and discounted prices.
\end{abstract}

Keywords: marketing mix, marketing strategy, region of origin, SEM-PLS, purchase decision

\begin{abstract}
Abstrak: Tujuan penelitian ini adalah 1) Menganalisis pengaruh bauran pemasaran, kesadaran merek, citra merek dan daerah asal pada keputusan pembelian lapis talas bagi wisatawan di kota Bogor, 2) Menciptakan strategi pemasaran yang efektif untuk pengembangan bisnis. Penelitian ini menggunakan metode SEM-Partial Least Sequare. Penelitian ini dilakukan dengan sampel sebanyak 160 responden. Responden yang dipilih adalah wisatawan yang datang ke kota Bogor dan telah membeli kue lapis talas. Dari hasil penelitian, diketahui bahwa variabel kesadaran merek, citra merek, produk, promosi dan wilayah asal memiliki pengaruh yang signifikan sedangkan variabel tempat tidak memiliki pengaruh yang signifikan. Strategi yang direkomendasikan yaitu 1) Meningkatkan kesadaran merek dengan meningkatkan intensitas iklan di media sosial, membangun outlet di daerah pariwisata dan stasiun $K R L ; 2)$ Meningkatkan kualitas produk dengan menyediakan mesin wrapping, menggunakan kantong plastik untuk menjinjing produk, memperbesar ukuran produk dan menambahkan campuran buah; 3) Meningkatkan ciri khas daerah dengan menambahkan bahan talas dan membuat merek yang identik dengan kota Bogor; 4) Membangun citra merek melalui tagline; 5) Meningkatkan promosi menggunakan media online (facebook, Instagram dan twitter), billboard dan harga diskon.
\end{abstract}

Kata kunci: bauran pemasaran, strategi marketing, region of origin, SEM-PLS, purchase decision

${ }^{1}$ Corresponding author:

Email: ahmad.ridho8888@gmail.com 


\section{INTRODUCTION}

Bogor is a city with a strong attraction for tourists. With its cool weather, beautiful landscape with hills and mountains, historical sites, recreation areas, and strategic location nearby Jakarta, Bogor has become an attractive tourist destination. It is reported that not only domestic tourist but also a lot of international tourists have visited this city. The number of tourist keeps growing in last few years. We could see the growth of tourist visitation in Bogor in Figure 1.

One of Indonesian cultures while visiting or travelling other region is to buy souvenirs for their family and friends. It will be incomplete for them not to buy any. This habit has existed for a long time, moreover we could find souvenir shops in most of the cities as it is becoming trending. Looking at this potential condition, the entrepreneur especially those who work in creative industry, has created a food production which is related to tourism, combined with the region of origin. In manufacturing industry, food \& beverage processing industry is one of the highest contributor for PDRB (product domestic region bruto) in Bogor. For the last five years, the number of food $\&$ beverage processing industry keep increasing. We could see the it in Table 1.

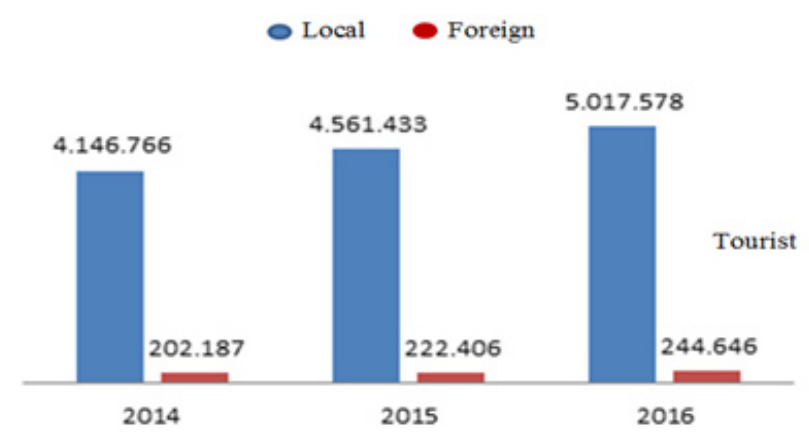

Figure 1. The growth of tourist visitation in Bogor started from 2012 to 2016 (Habibi, 2016).

Table 1. Food \& beverage industry's PDRB in Bogor City based on the price valid on 2013-2017

\begin{tabular}{rrc}
\hline Year & \multicolumn{1}{c}{ PDRB (Rp) } & Growth Percentage (\%) \\
\hline 2013 & $845,362,800,000$ & \\
2014 & $906,106,400,000$ & 7.18 \\
2015 & $1,027,551,700,000$ & 13.41 \\
2016 & $1,173,700,000,000$ & 14.22 \\
2017 & $1,313,900,000,000$ & 11.95 \\
\hline
\end{tabular}

Source: BPS of Bogor (2018)
Based on Table 1, the PDRB's growth of food \& beverage industry in the last few years is one of the indications that food \& beverage business is growing, it means that this area has a good prospect to process. There are some food \& beverage industries related to tourism in Bogor such as Apple Pie, Macaroni Panggang, Roti Unyil, various pizzas, etc. Among those various food, there is a very famous food often consumed by Bogor citizens and become food souvenir, it is called "lapis talas". Lapis talas has become a very famous and fancied product because this food is different from the others. It combines creativity with the region of origin, taro. Taro is one of the tubers grow in Bogor and has become the icon of the city. Taro is the second biggest "third harvest" commodity in Bogor, which is 2.360 ton per year (Sulthana, 2016). The overflowing of taro is an opportunity for business. Taro has a lot of benefits. It could be used as rice because it has a high carbohydrate, as herbal medicine, and in addition, it could be used as cake's basic ingredient. Taro layered cake or Lapis talas is one of the iconic food from Bogor. Lapis talas is made of taro flour mixed with wheat flour (Sukardi, 2014). At the beginning, lapis talas was made just like any other cake. But as time goes by, lapis talas has become various following up to the market. It has now original, cheese, greentea, blueberry, strawberry, chocolate and some other mixed flavour. It was Lapis Bogor Sangkuriang who had created this cake for the first time at 2011. Fortunatelly, the response of citizens and the tourists in Bogor was positive, therefore many other cake shops started to produce the same cake, and also many new cake shops establised only to sell lapis talas. According to Febry (2016), there are 13 brands of lapis talas in Bogor. From those 13 brands, some brands has only one outlet, some has more that are located in strategic areas in Bogor. Lapis Bogor Sangkuriang (LBS) is one of the brand that has many outlets. Those 13 brands are G-Bread, Golden France, Jumbo (Jumpa Bogor), Kaya Bakery, Lapis Bogor Sangkuriang, Lapis talas Aida, Lapis talas Arasari, Lapis talas Kujang, Lapis talas Priangan Sari, Lapis talas Sari Pakuan, $\mathrm{Mr}$ Broncow, Rumah Talas Bogor and Vira Cake.

Since there are many lapis talas brands in Bogor nowadays, it is required to have a good marketing strategy to win the competition. This marketing strategy has to be made effectively so that it could influence the consumer purchase decision, and the business could continue. Purchase decision is one of the consumer behaviour. Consumer behaviour is the whole activities, actions, and psychological process that makes its action 
before transaction, after transaction, using and finishing the product and service after the transaction, or doing evaluation of the product. Consumer making decision process represents the activities of the consumer when they are deciding whether or not they need to purchase a new item (Kotler, 2000). It is important to know the factors that influence the consumer's purchase decision towards lapis talas. By knowing those factors, company could decide the right promotion strategy to win the competition. Consumer's motivation and behaviour could be known and understood by going through the research, although not prefectly, at least it could minimize the failure of marketing strategy. Consumer sovereignty brings the challenge but creative marketing people could influence both consumer motivation and behaviour by selling the product $\&$ service that meet the consumer needs.

If the pattern of consumer behaviour is well understood, it will be easier for management to find the right way to influence their behaviour. There are some methods that could be applied to influnce the tourist behaviour in making decision process of purchase the cake as souvenir, one of them is to use marketing mix strategy. This strategy could be used to influnce the consumer behaviour. Product, price, place and promotion components could be developed to attract the tourists, for example, producing a product with various flavor and sizes. Management could also use price as their strategy, they could put the price lower than the competitor as long as the margin is well taken care of, eventhough it could be less. Sometimes price has a huge contribution in consumer's purchase decision making process, especially for cake that has mostly female as market segment which quite sensitive to the price. Choosing a strategic location is a must. Souvenir shop should be located in a tourism area or nearby railway or bus station, so that the tourists could find the shop easily. As well as the promotion activities, management should be able to utilize the right media to promote the product. Product, price and promotion have significant impact towards consumer purchase decision making process (Payson and Karunanithy, 2016). Not all the component of marketing mix has significant impact towards consumer purchase decision, sometimes the product, price, place, and promotion have significant impact at the same time, even sometimes one of them has no impact at all. For expensive product and purchased withing a long period, and also utilized for a long time such as car, motor cycle, "place" from marketing mix will not affect significantly towards the purchase decision (Payson and Karunanithy, 2016). It will be different towards food that is consumed daily, all the components of marketing mix has significant affect towards consumer purchase behaviour (Wee et al. 2014) and ( Nguyen et al. 2015).

Besides marketing mix strategy, there are other factors which could be used to influence the consumer behaviour such as brand awareness, brand image, and region of origin. Brand awareness has an impact on consumer's purchase decision (Moisescu, 2009), in line with Macdonald and Byron's opinion (2000), Hoyer and Steven (2014) and Hsin et al. (2009) claim that brand awareness has a significant impact on purchase decision. Brand awareness is the beginning of transaction process. Aware of one brand will make a consumer finding out more about the brand itself, whether quality, funcion, and also price, and when it meets the consumer needs, there is a high possibility of transaction happened (Timpal et al. 2016). Brand image is also important in marketing. Brand image is the description of consumer's belief and association towards certain brand (Tjiptono, 2008). Building a strong brand image in consumer or customer's mind is a company's long term investment because brand is prestigious asset, a good image of a brand will influence the consumer's behaviour in decision making process of purchasing a product (Aberdeen, 2016).

Region of origin's variable is one of the variables which is related to tourist's souvenirs purchase. When visiting a region, tourist tends to look for unique things that is identical with the area. The same thing goes to souvenirs, they will try their best to find a product that represents the site (McCutcheon et al. 2009). Using or consuming the product from the tourism place will make the consumer feel proud because it means that he or she has visited that place. In a product purchase process, consumers are not only concerned about the quality but also the region of origin factor. This factor is also influencing them whether to purchase the product or not. In consumer's point of view, using an city's iconic product makes them feel proud (Jailani, 2013). Looking at above phenomenon, it is very interesting to conduct a research about consumer purchase behaviour and the factors that influence tourist's purchase behaviour towards lapis talas as souvenir.

The objective of the research is to analyze the impacts of marketing mix, brand awareness, brand image and region of origin on the purchase decision of the tourist 
in Bogor towards food souvenir lapis talas. After finding the variables that influence lapis talas purchase decision, we will formulate the marketing strategies of managerial implication that could be used by the entrepreneur of the cake. This research focuses on the behaviour of the tourist who come to Bogor and purchase lapis talas as souvenir. It covers the marketing mix, brand awareness, brand image and region of origin, to figure out their impact on tourist behaviour in purchasing lapis talas as souvenir from Bogor. The respondents chosen for this research were the tourist that had ever visited Bogor and purchased lapis talas as souvenir within the last year.

This research approach is SEM-PLS (Structure Equation Model-Partial Least Square). According to Ghozali (2012) SEM-PLS's aims to test the predictive relationship between the constructs by finding out whether there is a relationship or the impact between them. SEM-PLS has more strength than regression and path analysis, it could discover the relationship among latent variables, as well as between latent and manifest variable. It could also be used to test the model without any strong basic theory, to decline the assumptions (non parametric) and accuracy parameter of predictive model that is seen in coefficient of determination value (R-square), therefore SEM-PLS is most suitable approach for research that aims to elaborate the theory.

The research position towards the previous ones are the variable used and the sample respondent. The previous research was hardly talk about region of origint variable towards the purchase decision. The respondent of this research is more specific which is the tourist of Bogor.

\section{METHODS}

This research was held in Bogor because this city is a tourist destination with high number of visitors. It also has many products represent the city. The questionnaire was distributed in Bogor Botanical Garden, Bogor Railway Station, Baranang Siang terminal, and Damri pool bus. Those areas were chosen because it gathered many people they were the access for the tourists to come and go from Bogor to their place of origin. This research was conducted within four months starting from April to August 2018. It uses primary and secondary data. Primary data was taken from the respondent's response in the questionnaire and the interview with the tourist who came to Bogor and had purchased lapis talas as souvenirs no matter what the brand is. While the secondary data was taken from some other sources such as from ministry of tourism of Bogor, schientific publication, journal, media, and book as supporting data.

The number of the reserach sample is according to the opinion of Hair et al. (2006), five to ten times from the number of indicator. The number of indicator of this research is 32 , if we multiple by five, the result of minimum sample needed is $160(32 \times 5)$ respondent. This reasearch uses two analysis: quantitative and qualitative analysis. The qualitative data was proceed by using descriptive analysis. Meanwhile, the quantitative data was proceed using statistical method which is SEM-PLS. SEM-PLS has two strengths comparing to regression and path analysis. It could figure out the relationship among latent variables, as well as the relationship between latent and manifest variable. SEM-PLS could be used to test the model without strong basic theory. This analysis begins with the iner model analysis at first to figure out the relationship between the latent and manifest variable.

The model design in this research could be seen in Figure 2, it is shown that there are seven independent variables that influence the purchase decision of lapis talas as souvenir, such as brand awareness, brand image, product, price, place, promotion and region of origin.

According to above research model which was inspired by the previous researchers and experts, as the introduction and exposure, below are the hypothesis that will be tested in this reasearch:

H1: Brand awareness has significant impacts on the purchase decision of lapis talas

$\mathrm{H} 2$ : Brand image has significant impact on purchase decision of lapis talas

H3: Product has significant impact on purchase decision of lapis talas

H4: Price has significant impact on purchase decision of lapis talas

H5: Place has significant impact on purchase decision of lapis talas

H6: Promotion has significant impact on purchase decision of lapis talas

$\mathrm{H7}$ : Region of origin has significant impact on purchase decision of lapis talas 
The operational definition of a variable is a set of validation tools that defines what variable should be observed and measured or a concept to test the perfection. This operational definition is needed to explain the identified variable as the understanding effort of the research. The variable used in this research is the purchase decision of lapis talas as souvenir from Bogor as dependent variable. While independent variables such as marketing mix, brand image, brand awareness and region or origin, are expected to have the impact on purchase decision. Each variable then measured based on the indicators based on previous research's theory and based on the reseracher himself which is considered relevant with the purpose of this research. The data of variable operational definition could be seen on Table 2 .

\section{RESULTS}

\section{Respondent Characteristics}

The respondent characteristic in this research are dominated by youth with $67.5 \%$ are $\leq 30$ years old and $32.5 \%$ are $>30$ years old. The respondent is dominated by $65.6 \%$ female and $34.4 \%$ male, while the respondent from Jabodetabek is dominating with the number of
$68.1 \%$, and from outside Jabodetabek is $31.9 \%$ As for the brand, the most consumed lapis talas is from Lapis Bogor Sangkuring (LBS), it is shown that $96 \%$ of the respondent had consumed the cake, Rumah Talas is $56 \%$ and Arasari is $19 \%$. Whereas for the percentage of the other 10 brands, the use of the product is very low which is under $10 \%$. For the number of purchase, $94 \%$ of the respondent purchased more than 1 pes, whereas the number of respondent who bought only 1 pcs is very low, which is only $6 \%$.

\section{Model Fit Measurement}

Measurement model fit is conducted by testing the validity and reliability of the outer model so that data used in the test has the validity and reliability. Outer model analysis specify the relationship between the latent variable and its indicators or we could say that outer model defines how each indicator related to its latent variable, which is used to test the validity. If the value is $>0.7$ or $>0.5$ and the value obtained is AVE $>0,5$ and the communality is 0,5 , we can say that the indicator "i" is valid (Ghozali, 2014). The reability in SEM-PLS could be decided by looking at the value of composite reliability and cronbach's alpha. Composite reliability and cronbach alpha's value must be $>0.6$.

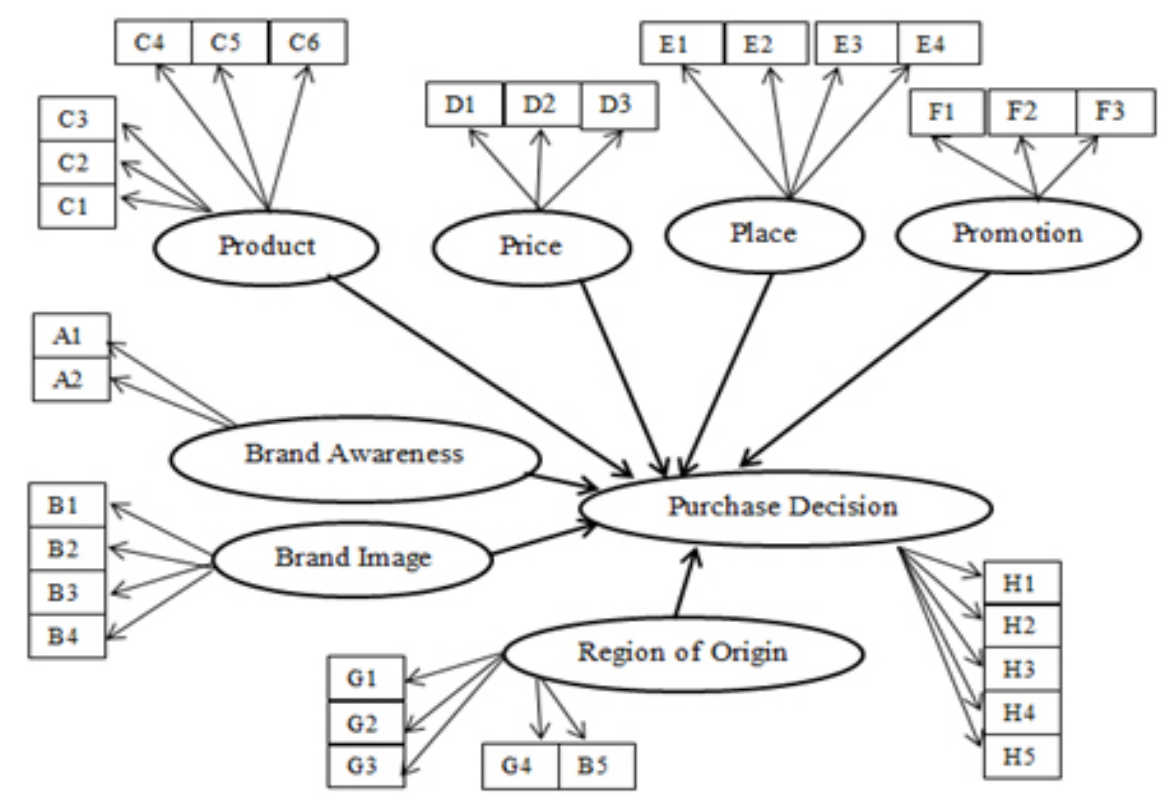

Figure 2. Reserach model 
Table 2. Variable operational definition

\begin{tabular}{|c|c|c|c|}
\hline Variabel & Indicator & Symbol & Sources \\
\hline \multicolumn{4}{|l|}{ Exogenous Variabel } \\
\hline \multirow[t]{2}{*}{ Brand Awareness } & Top of mind & A1 & Aberdeen (2016) \\
\hline & Previous known bran & $\mathrm{A} 2$ & \\
\hline \multirow[t]{4}{*}{ Brand Image } & Brand popularity & B1 & Aberdeen (2016) \\
\hline & Product halalness & $\mathrm{B} 2$ & \\
\hline & Healthy ingredient & B3 & \\
\hline & Natural ingredient & B4 & \\
\hline \multirow[t]{6}{*}{ Product } & Flavour & $\mathrm{C} 1$ & Rasyid (2016) \\
\hline & Aroma & $\mathrm{C} 2$ & \\
\hline & Size & $\mathrm{C} 3$ & \\
\hline & Color & $\mathrm{C} 4$ & \\
\hline & Durability & $\mathrm{C} 5$ & \\
\hline & Strong packaging & C6 & \\
\hline \multirow[t]{3}{*}{ Price } & Product's conformity & $\mathrm{D} 1$ & Rasyid (2016) \\
\hline & Affordable price & D2 & \\
\hline & Payment method & D3 & \\
\hline \multirow[t]{4}{*}{ Place } & Many outlets & E1 & Rasyid (2016) \\
\hline & Reachable & E2 & \\
\hline & Shop's cleanliness coziness & E3 & \\
\hline & Shop's coziness & E4 & \\
\hline \multirow[t]{3}{*}{ Promotion } & Discount & $\mathrm{F} 1$ & Rasyid (2016) \\
\hline & Online promotion & $\mathrm{F} 2$ & \\
\hline & Billboard promotion & F3 & \\
\hline \multirow[t]{5}{*}{ Region of origin } & Taro basic ingredient & G1 & McCutcheon et al. (2009) \\
\hline & Taro unique taste & G2 & \\
\hline & Unique aroma of taro & G3 & \\
\hline & Packaging that represents Bogor & G4 & \\
\hline & Brand that represents Bogor & G5 & \\
\hline \multicolumn{4}{|c|}{ Endogenous Variabel } \\
\hline \multirow[t]{5}{*}{ Purchase Decision } & Purchase time & $\mathrm{H} 1$ & Rasyid (2016) \\
\hline & To recommend & $\mathrm{H} 2$ & \\
\hline & Number of purchase & $\mathrm{H} 3$ & \\
\hline & Purchase to be souvenir & $\mathrm{H} 4$ & \\
\hline & Purchase to be consumed & $\mathrm{H} 5$ & \\
\hline
\end{tabular}

After the statistical test done, there are some indicators with loading factor $<0.5$ and the variable AVE value is $<0.5$, so that it must be deleted. After being deleted, the retest is done to obtain the accurate model. You could see the model with the deleted indicator and variable because they are not valid and reliable in Figure 3. According to above figure, there is one deleted variable which is price. Price is deleted because its composite reliability value is $<0.6$. The data of construct validity and reliability could be seen in Table 4 .

\section{Structural Model Fit}

Structural model analysis was conducted to ensure that the structural model was built accurately. According to the value of R-square on Table 5, it is discovered that Brand Awareness, Brand Image, Product, Place, Promotion and Region of Origin are able to explain the types of Purchase Decision with the percentage of $46.1 \%$, whereas the $53.9 \%$ could be explained by other variable that is not examined. 


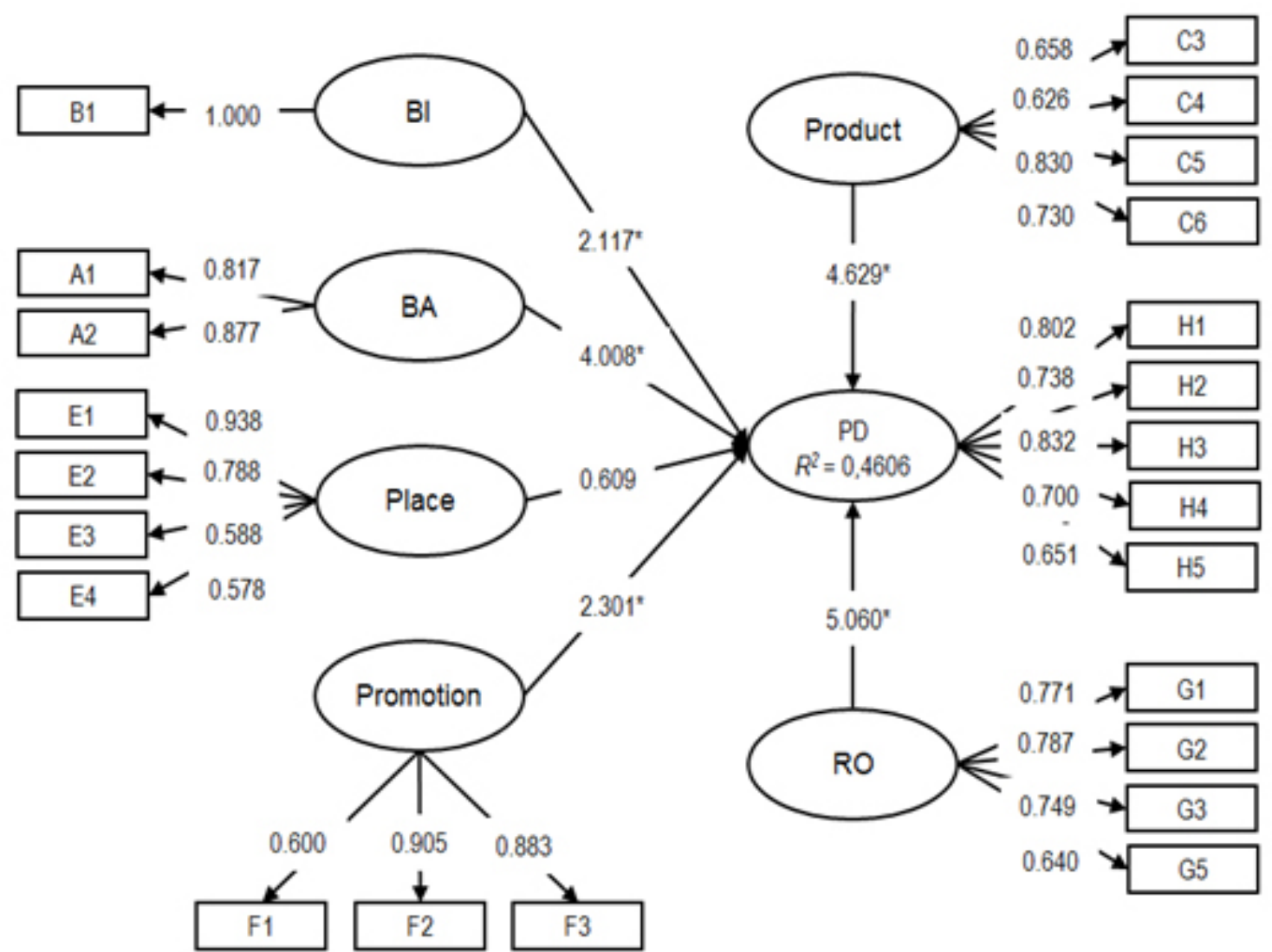

Figure 3. The model after the invalid and unreliable indicator and variable deleted

Table 4. Construct validity and reliabelity

\begin{tabular}{lcccc}
\hline Variabel & Cronbach's Alpha & Composite Reliability & AVE & Communality \\
\hline Brand Awareness & 0.610 & 0.836 & 0.718 & 0.718 \\
Brand Image & 1.000 & 1.000 & 1.000 & 1.000 \\
Product & 0.777 & 0.822 & 0.546 & 0.512 \\
Place & 0.703 & 0.805 & 0.512 & 0.546 \\
Price & 0.379 & 0.759 & 0.614 & 0.634 \\
Promotion & 0.736 & 0.846 & 0.653 & 0.653 \\
Region of Origin & 0.723 & 0.827 & 0.546 & 0.546 \\
Purchase Decision & 0.800 & 0.863 & 0.559 & 0.559 \\
\hline
\end{tabular}

Effect of Brand Awareness, Brand Image, Product, Place, Promotion and Region of Origin Variables on Purchase Decisions

After bootstrapping done for structural model fit, the value that could be used to reject and accept a hypothesis is obtained. There are five variables that have significant impact on the purchase decision of lapis talas as souvenir and one variable that has no significanat impact. A variable considered significant if the value of T-statistic is $>$ T-table $\alpha=5 \%$ (1.96). We could see how sinificant the impact is from the value of path coefficient. The test result towards the hypothesis with Bootstrapping in the research could be seen on Table 4 .
After testing the impacts among variables, the result shown that Brand Awareness has a positive and significant impact on purchase decision. It could be seen in path coefficent value which is 0.278 and the T-statistic which is 4.008 . There are two indicators on brand awareness variable. Brand indicator which is known before (A2) is the strongest indicator. The result of this research is in line with the previous research done by Timpal et al. (2016) and Cahyani (2016) which claims that brand awareness has significant impact on purchase decision. 
Table 4. Hypothesis test result

\begin{tabular}{lccc}
\hline Hipotesis & Path coefficient & T-statistik & Significance \\
\hline Brand awareness $\rightarrow$ purchase decision & 0.278 & 4.008 & Significant \\
Brand image $\rightarrow$ purchase decision & 0.176 & 2.117 & Significant \\
Product $\rightarrow$ purchase decision & 0.241 & 4.629 & Significant \\
Place $\rightarrow$ purchase decision & -0.030 & 0.609 & Not significant \\
Promotion $\rightarrow$ purchase decision & 0.127 & 2.301 & Signifikan \\
Region of origin $\rightarrow$ Purchase decision & 0.196 & 5.060 & Significant \\
\hline
\end{tabular}

Brand image has positive and significant impact on the purchase decision of souvenir lapis talas. It is shown that the path coefficient value is 0.176 and T-statistic is 2.117. Brand image has brand popularity indicator. It shows us that tourists do consider image of popular brand when purchasing lapis talas as souvenir. This research is in line with the result of the research conducted by Nur (2014) who did the reseach to traditional food product. The result of that research shows that brand image has significant impact on purchase decision. While Rahmawaty (2014) has different result where brand image has no significant impact on purchase decision.

Product variable has positive and significant impact on purchase decision of lapis talas, with the value of path coefficient is 0.241 and the T-statistic is 4.629. There are four indicators in product variable. Product durability (C5) is the strongest indicator. This research's result is in line with the research done by Siburian et al. (2018) which claims that product variable has significant impact on purchase decision. The similar result was also revealed by Pertiwi (2016) where the product has significant impact on purchase decision.

The place variable has negative and insignificant impact on the purchase decision towards souvenir lapis talas. Results shown that the path coefficient value is $-0,030$ and T-statistic value is 0.609 . It means that place variable is not something to be considered by the tourist when they purchase the souvenir lapis talas in Bogor. To get the product they wanted, it is not a problem for them to travel farther. With the existence of online public transportation, tourists do not have to come by themselves to the shop to purchase the souveni. This result is not in line with the one conducted by Natakusumah (2016) and Anindityo et al. (2017) which claims that a place has a positive and significant impact on the purchase decision.
Promotion has a positive and significant impact on the purchase decision of lapis talas. It is shown from the path coefficient value which is 0.127 and the T-statistic value which is 2.301. Online media promotion (F2) is the strongest indicator in this variable. This result is in line with the one of Bairizki (2017), where his research shown that promotion variable has significant impact on purchase decision. Hermawan (2015) and Rahmalia (2016) have an in line result that said promotion has significant impact on purchase decision.

Region of origin has positif and significant impact on purchase decision. The path coefficient value is 0,196 , T-statistic is 2, 559 and the P-value is 0,011 . The unique taste of taro (G2) is the strongest indicator in this variable. This research is in line with with that one of Jailani (2013) which claims that the region of origin has a significant impact to purchase decision.

\section{Managerial Implications}

The statistic test results on the variables that have significant impact on purchase decision claims that there are five variable that have significant impact which are brand awareness, brand image, product, promotion and region of origin. Therefore it occurs that some marketing strategies are recommended to be used by entrepreneur whose position is still as market follower in lapis talas business.

The first strategy is to increase tourist's brand awareness of lapis talas. This strategy could be done by (1) Making an exhibition or building a souvenir outlet in a reachable and accessable location for tourist. As the most tourists are from Jabodetabek, Bogor railway station, toll exit area, and Bogor Botanical Garden are strategic locations to hold the exhibition. (2) Applying reseller system and collaborate with the cake shop by giving discounted price. This kind of way is very suitable for market followers who are not strong 
enough financially as they do not have to open their own outlet. (3) Increasing the intensity of promotion specially through social media because it does not cost a lot. (4) Making writing or blogging competition about lapis talas and posting it to social media so there will be a lot of social media users read or see the article.

Product is one of the most considered factor in purchase decision. The flavor, aroma, size, durability and packaging are parts of a product that will be valued by consumer. Market followers could imitate some of market leader's product characteristics, but they still are able to create their own product with its own uniqueness and excellence. To increase the product quality, it is suggested to (1) To provide wrapping machine so the product will be airtight so that the product will be more durable. Wrapping machine is used after lapis talas packed in a box. There is no brand of lapis talas that uses this this strategy at the moment. This strategy could be an added and unique value for the brand. (2) Managerial implication suggested is to make a plastic bag for the product outer packaging. (3) The product size must be made bigger than the product in the market. The unit profit will be less a little, but it will not be a problem if selling volume increases. Producer could also enlarge cake mold lessen the thickness so that the size looks bigger. (4) The product's color could me made more attractive. We could add some mixed fruits or vegetable with bright color such as dragon fruit, screwpine leaf, carrot, strawberry, manggo, bit, etc to the cake dough.

Region of origin is a variable which is really related to the tourist. The strategy suggested to the entrepreneur or to the prospective entrepreneur is to create a product that has more specifict and unique taste, dominant basic ingredients, stronger aroma, and a strong brand that really represents Bogor. There are some names suggested to be the brand's name of lapis talas: "Lalas Kabayan" which is the abbreviation of Lapis talas Kabayan, Lapis talas Kota Hujan, Lapis talas Pasundan, and Lapis talas Wilujeng.

Building a brand image is one of the strategies that should be done by the entrepreneur. It could be done by attaching the image wanted into the tagline, just like LBS did. Their tagline is "The first and the biggest". That tagline is written in the caption of every article, photo, or video posted in social media.
The next suggested strategy is to promote the product. It is suggested to utilize some medias such as (1) online media, both company website and social media account such as instragram, twitter and facebook. (2) Using billboard in the route passed by the tourist such as railway station, toll roadsides, along the way to the tourism destination to promote the product. (3) Giving discounted price or other services with certain terms and condition.

\section{CONCLUSIONS AND RECOMMENDATIONS}

\section{Conclusions}

According to the result of the research, there are some conclusions such as (1) From the 6 variables expected to have an impact on purchase decision, there are five variables that have significant impact such as brand awareness which has the strongest impact, and then product, region of origin, brand image, and promotion variable. Place variable has no significant impact on the purchase decision. (2) There are main strategies recommended such as doing promotion by online media and around the area where many tourists usually gathered, providing wrapping maching for strong packaging, and creating stronger taste of lapis talas.

\section{Recommendations}

According to the value of R-square, which is $46,1 \%$, the purchase decision types of lapis talas could be explained in this research, but there are still 53,9\% other types that could not be. It is suggested to the next researcher to be able to analyze the other variables outside this research for example word of mouth (WOM) variable, because during the interview with the respondent, many of them informed that they find out about lapis talas's brand from their friends and family, it means that there will be more useful research for either entrepreneur or propective entrepreneur of lapis talas.

\section{REFERENCES}

Aberdeen NI. 2016. Pengaruh kesadaran dan citra merek terhadap persepsi mutu dan minat beli konsumen. [tesis]. Bogor: Institute Pertanian Bogor.

Anindityo M, Sumarwan U, Tinaprilla N. 2017. The influence of marketing mix and consumer 
knowledge towards kefir mark consumer decision process. Brithis Jurnal of Marketing Studies 6(1):2053-4051.

Bairizki A. 2017. Pengaruh harga, promosi dan kualitas produk terhadap keputusan pembelian dalam meningkatkan penjualan di ratna cake and cookies. Jurnal Valid 14(2):71-86.

[BPS] Badan Pusat Statistik. 2018. Produk Domestik Regional Bruto Kota Bogor Menurut Lapangan Usaha. Bogor: BPS.

Cahyani KI, Sutrasmawati E. 2016. Pengaruh brand awareness dan brand image terhadap keputusan pembelian. Manajement Analysis Journal 5(4):281-288

Febry. 2016. Respon konsumen terhadap bauran pemasaran lapis Bogor sangkuriang. Institut Pertanian Bogor. Bogor: Institute Pertanian Bogor.

Ghozali I. 2014. Structural equation modeling, metode alternatif dengan partial least square (PLS) Dilengkapi software Smartpls 3.0 Xlstat 2014 dan WarpPLS 4.0 Edisi 4. Semarang: Universitas Diponegoro Semarang.

Habibi Y. 2016. Bogor menerima kunjungan 5 juta wisatawan. https://www.republika.co.id/berita/ koran/urbana/16/12/26/ois6472-bogor-[2018 Feb 23].

Hair JF, Anderson RE, Tatham RL, Black WC. 2006. Multivariate data analysis. 8th Ed. upper saddler river. New York: Prentice-Hall, Inc.

Hermawan H. 2015. Analisis bauran pemasaran terhadap keputusan, kepuasan dan loyalitas konsumen dalam pembelian Roti Ceria di Jember. Jurnal Manajemen dan Bisnis Indonesia 1(2): 143-161.

Hsin KC, Huery RY, Ya TY. 2009. The impact of brand awareness on customer purchase intention: The mediating effect of percceived quality an brand loyality. The Journal of International Management Studies 4 (1): 135-143.

Jailani AS. 2013. Pengaruh arga, kualitas produk dan region of origin terhadap keputusan pembelian kaos cak cuk di Surabaya.Jurnal Ilmu Manajemen 1(2): 600-611.

Kotler P. 2000. Manajemen Pemasaran. Jilid 2. Jakarta: Bumi Aksara.

Macdonald EK, Byron MS. 2000. Brand awareness effects on consumer decition making for a common, repeat purchase product: a replication. Jurnal of Business Research. 48: 5-15. https:// doi.org/10.1016/S0148-2963(98)00070-8.
McCutcheon E, Johan W, Elthon L. 2009. Region of origin and its importance among choice factors in the wine-buying decision making of consumers. International Journal of Wine Business Research 21(3): 212-234. https://doi. org/10.1108/17511060910985953.

Moisescu OI. 2009. The importance of brand awareness in consumer's buying decision and perceived risk assesment. Marketing \& Manajemen 7(1):103110.

Natakusumah FA, Yuliati AL. 2016. Pengaruh bauran pemasaran terhadap keputusan pembelian Ina Cookies Bandung. Jurnal Manajemen Teori dan Terapan 9(1): 34-49.

Nguyen TN, Thi THP, Phuong AV. 2015. The impact pf marketing mix element on food buying behavior: a study of supermarket consumers in Vietnam. International Journal of Business and Management 10(10): 206-215. https://doi. org/10.5539/ijbm.v10n10p206.

Nur KWM. 2014. Analisis pengaruh word of outh adan marketing mix terhadap keputusan pembelian prol tape primadona melalui brand image. [tesis]. Bogor: Institut Pertanian Bogor.

Payson SP, Karunanithy M. 2016. Impact of marketing mix on buying behavior a case study of motorbike buyer in Jaffna distrik. EPRA International Journal of Economic and Business Review 4(1): 132--137.

Pertiwi MI, Yulianto E, Sunarti. 2016. Pengaruh bauran pemasaranterhadapkeputusan pembelianBaker's King Donuts \& Coffee. Jurnal Administrasi Bisnis 37(1): 179-186.

Rahmalia W, Hakim DB, Budidarmo RR. 2016. Sikap terhadap marketing mix dan proses pengambilan keputusan pembelian konsumen pada Daebak Fan Cafe Depok. Jurnal Aplikasi Bisnis dan Manajemen 2(3):230-238. https:// doi.org/10.17358/JABM.2.3.230.

Rahmawaty P. 2014. Pengaruh brand image, kualitas produk dan harga terhadap keputusan pembelian Sari Roti. Jurnal Ilmu Manajemen 11(2): 82-89. https://doi.org/10.21831/jim.v11i2.11768.

Rasyid MHA. 2016. Analisis gaya hidup, inovasi produk dan bauran pemasaran terhadap keputusan pembelian produk hen's instant omelette (Studi kasus pada PT. Eco Nature Multiindo)[thesis]. Bogor: Institute Pertanian Bogor.

Siburian SE, Putu NM. 2018. Pengaruh bauran pemasaran terhadap keputusan pembelian bandung makuta cake. E-Proceeding of 
Management 5(1): 2355-9357.

Sukardi, Munggaran MLP. 2014. Usulan desain model bisnis Lapis Bogor Sangkuriang. E-Jurnal Agroindustri Indonesia 3(1): 2252-3324.

Sulthana GZ, Harisudin M, Setyowati N. 2016. Strategi agroindustri Lapis Bogor Sangkuriang PT. Agrinesia Raya. AGRISTA 4(3): 537-549.

Timpal N, Lapian SLHNVJ, Paulina PR. 2016. Pengaruh brand awareness dan brand attitude terhadap keputusan pembelian hanphone merek
Nokia (studi kasus pada siswa SMA dan SMK di ota Manado). Jurnal Berkalah Ilmiah Efisiensi 16 (1): 1-10. https://doi.org/10.30631/innovatio. v16i2.18.

Wee CS, Sokhi M, Zakuan N, Tajuddin MNM. 2014. Consumers perception, purchase intention and actual purchase behavior of organic food products. Integrative Business and economic research 3(2): 378-397. 